Social Sciences, Humanities and Education Journal (SHE Journal)

Volume 1 (3) 1 - 9, September 2020 | ISSN: 2720-9946 (Online) | ISSN: 2723-3626 (Print)

The article is published with Open Access at: http://e-journal.unipma.ac.id/index.php/SHE

\title{
PUBLIC PROCUREMENT IN AFRICA AND THE INTEGRITY QUESTION: TOWARDS AN ETHICAL NARRATIVE
}

Tom Eneji Ogar $\bowtie$, Department of Philosophy, University Of Calabar, Calabar - Nigeria Ushie Abel Idagu, Department of Philosophy, University of Calabar, Calabar - Nigeria

\begin{abstract}
This work is an analysis of public procurement and the role integrity and ethics play s in enhancing effectiveness and efficiency of the procurement system. The paper sit uates that though public procurement is a worldwide exercise where government spends public funds for the procurement of good s works and services, for the good of the people, inefficiencies has trailed the procurement system in most developing countries of Africa. Some of these countries have taken some steps to reform the sector, but there are still noticeable challenges and obstacles to a full maximization of the goals of a good procurement system. One of the major challenges, identified has been that of a dearth of integrity and ethical consciousness on the part of procurement professionals and stakeholders alike. It is essential that public procurement professional and stake holders adhere to a well -defined and established code of ethics. Ethics a re the principles which defines behavio urs as right, good and appropriate. Employees in public service are expected to uphold certain core values and any attempt to pursue personal interest using conduct that are not consistent with the proper discharge of the em ployee's duties is a breach of the public trust. In the public sector where procurement is funded by public expenditure, it is imperative that procurement operates with integrity, transparency and professionalism. In most African countries, Nigeria, Uganda, Tanzania to mention a few, the ethos of an efficient system devoid of unethical behaviours by professionals has been far from achieved. The procurement systems have therefore been plagued by integrity and ethical issues leading to unwholesome and undesir able situations. A review of related literatures to these topics was carried out with a view to carry out a contextual analysis in addressing the specific issues under study. This work is therefore significant as it tried to apply ethics to a fundamental a spect of governance which is the procurement of goods, services and works for the ultimate benefits of the populace.
\end{abstract}

Keywords: Public Procurement, Ethics, Africa, integrity question.

$\bowtie$ enejiogar93@gmail.com

Citation: Ogar, T. E. \& Idagu, U. A. (2020). Public procurement in africa and the integrity question: Towards an ethical narrative. Social Sciences, Humanities and Education Journal (SHE Journal) , 1(3), 1 - 9. DOI: $10.25273 /$ she.v1i3.7549

\section{(c) BY-NC-SA}

Published by Universitas PGRI Madiun. This work is licensed under the Creative Commons Attribution NonCommercialShareAlike 4.0 International License. 


\section{INTRODUCTION}

The public procurement function today is no longer a series of tasks that one simply throws at someone in the back office without any further care in the world. In fact, to underestimate procurement is much like pretending that one is doing business (Snider \& Rendon 2012; Bessong et al., 2018; Okpo 2020). This style of thinking was in the old. But even earlier days than that, there were no real procurement departments to speak of. Today, things are changing and also very fast too. Procurement professionals now sit at the high table. These trained professionals have taken on a weighty clout in government affairs. After the agencies of government are cleared from the budget departments, it is the procurement team that ultimately determine where best to spend budgeted public funds. Those who do not adapt to the new trends in this all important sector can only find themselves in financial peril which may ultimately affect service delivery to the people. The procurement reforms in some countries of the African continent began not long ago. According to Didas Bukunzi in his paper "Recalling where African procurement reforms began" has this to say;

Nearly 10 years ago, about 30 participants from across Sub Saharan Africa gathered in Abidjan, Ivory Coast to address public procurement challenges and opportunities. The conference was co-sponsored by the International Trade Centre, the African Development Bank, the World Bank and the United Nations Development programme. These institutions all felt that financial efficiencies in African governments were being compromised, not only by outright corruption, but more importantly a lack of proper procurement rules (Bakunzi: 2008, pp. 16-17)
The 1999 Abidjan consensus document on public procurement reform has undergone some fundamental positive developments. Before the reforms, the Central Tender Boards, saddled with procurement functions had become overwhelmed and even the word procurement was loaded with technicalities and mystery. At the moment, this is no longer the case because many governments have over the years taken on board the basic principles of public procurement best practice and are gradually seeing savings in their annual expenditures.

From Ghana and Nigeria in West Africa to South Africa and Uganda, Kenya and Tanzania in East Africa much has been accomplished in the public procurement sectors of these governments. However, the case of the procurement reforms in East Africa is of special significance. According to Odhiambo and Kamau (2009, pp. 74);

The three East African countries share a common political and economic history that dates back to the colonial period. On attaining independence in the early 1960's, the three countries inherited almost similar economic and political procurement in the three countries was largely undertaken by external entities such as the Crown Agents. This was primarily because most of the needs of then colonial governments and the incoming new governments could only be met from external sources as local supplies were still not adequate. With increasing procurement needs, the three governments found it necessary to pass over the responsibilities of procurement to ministries.

Public procurement has undoubtedly become an increasingly important issue in economic circles globally (Duraku 2018). This is evidenced by the growing interest of donors, professional 
organizations and the general public on matters of public procurement. The review and reforms of the institutional framework and procedures in public procurement has yield important conclusions such as clear regulations and laws, decentralization of procurement activities and so on. As much as these results have been recorded over the period, improving integrity and work ethics in which public good is valued more than individual interests is a major issues that require attention.

\section{THE NARRATIVES}

This section takes a look at integrity and work ethics and how these issues affect the public procurement subsector. Ethics play a major role in procurement and are considered more important as technology and consumer behaviour change. Being ethical entails being in accordance with the rules and standards for right conduct or practice especially as it has to do with the standards of a given profession.

Ethics is therefore concerned with the moral principles and values which govern our beliefs, actions and decisions (Kidzu \& Ncha 2018; Ncha 2018). There is much emphasis on the "moral" aspect of ethics because while it is very important, many people would take the view that there are good practical reasons why it is important for procurement professionals to be people of high integrity and behave ethically (Carter \& Kirby, pp. 2006). The general outlook of most code of ethics is that buyers should not allow anything to impair impartiality. That is, buyers or procurement entities that are charged with spending public funds and should do so in a manner that is totally impartial. Here, contracts should be awarded to a supplier because the supplier represents the best value for money and not because the buyer is favouring that supplier for whatever reason.

The amount of public funds spent on government is enormous. According to Paul Stephens (2013), between 13 and 20 percent of a country's gross domestic product on the average is spent on procurement. This could even be higher in developing countries. Despite the huge public funds involved, the public procurement sector are some of the least professionalized in most government circles leadings to obvious challenge of corruption and other ethical issue. The attendant pressures which is brought on procurement entities of government by the wider market environment, makes it necessary that heads of agencies and the larger procurement professionals recognize and understand both the ethical and integrity standards needed in carrying out their duties and responsibilities.

As noted earlier, the importance of procurement ethics and integrity cannot be over-stated. Since professionals are the direct representatives of government agencies in doing business with suppliers, a sound integrity background with good ethical conduct is needed in dealing with suppliers of goods works and services. With this background in focus, it is but an aberration for procurement practitioners and professionals to claim the status of a professional in the field without due attention to ethical issues.

For the UN procurement practitioners handbook, the issue of integrity in procurement is fundamental as the UN procurement officers are expected to maintain superior standards of integrity and moral values in the conduct of their functions and duties (Mangla \& Luthra 2019). The handbook went further to identify integrity as "one of the fundamental, if not paramount, standards of conduct" which is underlined in Article 101 of the United Nations Charter. The report further explains integrity thus;

Integrity, while perhaps not subject to exhaustive and precise definition, must be judged on the basis of the total behaviour of the person concerned. Such 
elementary personal or private qualities as honesty, truthfulness, fidelity, probity and freedom from corrupting influence, are clearly included. (UN procurement handbook).

The point of departure from the above analysis is that a procurement professional by that name is one who is seen to have dedicated himself to regulate his conduct with the interest of the public in view. In as much as the charter is specific on the United Nations as a body, it also applies to governments and their agencies involved in public procurement. Generic principles of integrity that goes beyond the rise above cultural differences of nationality and ethnicity must be allowed to prevail. Integrity to a procurement professional in general entails that the public trust is so fundamental that it cannot be compromised. In the same vein, a professional in the procurement sector, must be seen at all times to demonstrate integrity by acting without consideration of personal gain, resist undue political pressure in decision making, not abusing power or authority and ultimately taking prompt action where unprofessional or unethical behaviours are noticed.

The concept of unethical behaviours in public procurement is widespread in literatures. The intention of an individual to act in an unethical manner can be seen as the expression of one's commitment to engage in a behaviour that is unethical. An unethical behaviour can therefore be described as any action(s) that seem to violate widely accepted moral norms of the society. In this regard, if an ethical issue is identified and a process to solving it is sought out, it invariably a means of showing if a behaviour is right or wrong (Carter \& Kirby 2006). Some examples of unethical behaviour in procurement have been identified over the period. Though not limited to those issues, the commonly mentioned and discussed are; accepting supplier favours and gifts, conflict of interest, confidentiality of information, fair and unbiased treatment and of course integrity. The acceptance of gifts from suppliers though contentious is the most common unethical practice in procurement. This may affect buyers decision to evaluate and select a fit for purpose suppliers. In many countries, giving of gifts by suppliers is common practice. It is often said that gifts are a way of "saying thank you" for past business transaction and should not be seen as a "softener" for future business. Perhaps not, but when gifts become much larger and more valuable, it is pertinent to ask if the supplier is offering the gift for the benefit of its corporate health or whether it expects something tangible, such as a large contract in return. If contracts are awarded to suppliers because the procuring entity knows that it will continue to receive gifts from the supplier, then public funds held in trust by a government entity is not being spent impartially. Unethical behaviours by procurement professionals could lead to misprocurement and ultimately to a total collapse of the procurement sector thereby leading to lack of value for money.

With regard to the above, public procurement would mean, the purchasing, hiring or the process of obtaining by a contract of goods, works and services by the public sector (Erridge 2000). In other words, public procurement means the purchase of commodities and contracting of construction works and services if such acquisition is affected with resources from public funds and budget either from state, local authority or national governments. The items involved in public procurement range from simple goods or services such as clips or cleaning services to large commercial projects such as the development of infrastructures, including roads, power stations, train stations and airports. The public procurement goals include; satisfying the customer in terms of cost, quality and in timely manner, minimizing 
costs, conducting the process with integrity, transparency and ultimately fulfilling desired public objectives. Witting (1998) noted that, unlike
private procurement, public procurement is a business process within a political system and thus has significant consideration of effectiveness, integrity accountability and local state or national interest. Still on the importance of public procurement, Thai (2001) estimate that the size of public procurement varies between 5 and 8 percent of GDP in most industrialized countries. The magnitude of that in Africa and the Middle East ranges between 9 and 13 percent. These statistics show that public procurement is significant in the economies of both the developed and developing countries. Judging from the importance of public procurement as shown above, ensuring that the process is efficient is rather crucial and fundamental. It requires therefore that the whole process is well understood by practitioners, stakeholders and the general public. Unfortunately, for most developing countries in Africa this is far from the case. Although some of these countries like Ghana, Nigeria, Uganda, South Africa etc. have taken steps to reform their procurement systems, the process is still shrouded in corruption, secrecy and inefficiency (Chikwe \& Obi 2016). In all these cases, huge amount of public funds and resources are lost. Thus effective and efficient application of public resources has remained a major challenge facing many countries around the world.

At every level of governance unethical procurement in the public procurement process impacts directly or otherwise on the quality of social services that are intended to benefit the poor. The strategy to address corruption and integrity issues in public office reveals that corruption has led to significant loss of public resources through mishandled procurements and outright embezzlement. The central issue of ethics and its application in public procurement has become imperative.
Over the period, attention on public procurement reforms have been on legal and institutional training and capacity building of procurement professionals without due attention to procurement ethics. However, in the area of corporate image and best practices in corporate social responsibility, ethics and ethical foundations are seen as core industry indicators for success.

The abysmal level of compliance to public procurement regulations by procurement professionals and stakeholders in most developing countries of Africa in particular and elsewhere are strong cases of unethical practices (Nwogwugwu \& Adebayo 2015). Unethical conducts ranging from high incidence of vested interests, interference and insider dealings and occasional cases of retrospective approval of contract awards are rife in most public procurement systems of developing countries under review. In Nigeria for instance, with a public procurement Act (2007) in place, supported by regulations, guidelines and standard bidding documentation, enforcement of compliance has continued to be a formidable challenge (Muhammad et al., 2015). This is not to conclude that regulations and other documents put in place are not important but that ethical issues should equally be considered as fundamental in public procurement as procurement is basically an ethical cum integrity laden domain.

As noted by Ayoyi \& Mukoswa (2015, pp. 65), "the rise of supply chain management and procurement in Kenya is associated to a number of unethical practices that violates code of conduct". The import from the above is that when a bidding process is not carried out according to rules and regulations but done in secrecy, suppliers may be forced without option than to solicit for contract jobs by other forms of solicitation like bribe giving. Fair and unbiased treatment in the bidding process, avoidance of conflict of interest, integrity, 
accountability and a good and responsible procurement system have a positive outlook on the entire procurement value chain and could in the long run translate into overall performance and service delivery. Integrity and ethical codes are central in this regard but without equally compromising clear rules, regulations, laws and the capacity of professionals.

As earlier observed, it is basically through modern public procurement models that government at all levels applies public resources for the procurement of goods, works and services for the good of the populace. With the huge resources governments spend on annual public procurement, it creates a huge market for contractors and suppliers thereby creating an avenue for fraud, corruption and related acts. In this regard, it is not out of place to ensure that water tight measures are put in place to safeguard the procurement subsector for the ultimate benefit of the people. Public procurement reforms have been carried out in most developing countries of Africa including but not limited to Nigeria, Uganda, South Africa, Tanzania and Ghana. These reforms have also seen the development of policies, rules, regulations and laws to regulate public procurement in all these countries. They are basically intended at assisting entities of government saddled with the responsibility of procurement in checking procurement fraud and other corrupt practices Standard Bidding Documents (SBD) arising from the various procurement laws and regulations are also developed to highlight the various methods of procurement under different conditions and the situations that could lead to procurement.

\section{CONCLUSION}

The need and impetus to reform the procurement sector in recent years has increased partly in consequence of the requirements set up by most donor organisations as conditions providing development assistance to developing countries and primarily because inefficiencies of the unreformed systems have become self evident. Donor partners also consider that a well functioning procurement regime is an essential requirement if their funds are to be effectively applied to promote development. In this regards, there is need for a total overhaul of the procurement system to focus on the principles of efficiency and effectiveness of the sector. Aside building the capacities of procurement professionals for competency and efficiency, there is also a compelling need to improve on the integrity and ethical code of practitioners in the field. In the words of Ayoyi and Mukoswa, $(2015,64)$ "the more ethical practices are adhered to in public organization, the better the effectiveness of the procurement process and hence the more customers will be satisfied. Gone are the days where people misconstrue public funds as "government money". If public funds and resources are to be held in trust for the people by the officials of government, then there is absolute need for proper accountability. It is only where the public domain adheres to strong integrity and ethical ethos that fairness and accountability can be seen to thrive.

There is still a lot of unethical behaviours and attendant corruption in the procurement system of most developing countries inspire of the ongoing reforms. Most of these unethical issue are done in utmost secrecy, but manifested in wrong computation of costs by evaluation teams, poor performance of construction works, failure to complete performance contracts on time or not at all etc. The main reason for the out look as has been shown by this research is that not much has been done on integrity and ethical training of practitioners and stakeholders in the sector.

Bribery and corruption have been seen as biggest obstacles to public procurement reform in developing 
countries (Williams-Elegbe 2018). This is primarily due to the low level of the ethical narrative. Right from the point of recruitment of procurement professionals, integrity test should be conducted on personnel and thereafter strong policy on procurement should include codes of ethics, which can ultimately influence the entire procurement sector.

\section{Recommendation}

Reform in the procurement sector is a protracted process with many obstacles. The establishment of a legal framework and the regulatory institution are the first and possibly the easiest steps in the reform process. Enforcing compliance with the law and the eradication of institutionalized corruption are the more difficult steps that may take longer period of time to achieve. While acknowledging the shortcomings, we must also recognise the process that have been made already in the countries where public procurement is being conducted according to standards of integrity, transparency and value for money than those which obtained before he reforms began.

Efforts at fostering procurement operations and market practices and the integrity of the system is therefore germane in the relationship between the public entities of government and the contractors, seen as the critical stakeholders.

All procurement practitioners must be technocrats with requisite professional training and competencies, rather than the appointment of practitioners on political considerations. This will ensure that the bidding process is carried out from the position of knowledge of the system. The frequent resort to cast blame on the procurement process as being responsible for slow budget implementation will be addressed. Ethics play a major role in procurement and is considered more important than technology and consumer behaviour change. To be ethical means being in accordance with the rules or standard or right conduct and practice. Professionals in procurement must carry out their trade in the most ethical manner. Failure to abide by ethical practices can lead to unethical practices such as illegal sourcing, bribery, favouritism etc. It is important to note that procurement professionals face enormous pressure from external and internal forces to act in unethical ways as they usually have control over large sums of public funds. The immediate reaction to the idea of unsatisfactory procurement ethics is that it will be damaging for public relations, if those ethics become public knowledge.

An ethical and integrity policy should as a matter trust be put in place by all procurement entities of government, that is, a written policy making it clear what top management considers ethical and what it considers unethical and this should be made readily available to all stakeholders. This work also submits that besides creating a policy trust based on integrity and ethical code of conduct, ethical training should be made compulsory for all procurement professionals prior and after engagement as procurement practitioners in any public domain. An innovative training will provide employees with all the important information about integrity and ethics so that they are able to apply to their schedules in an ethical manner.

Since integrity is the quality of being honest with strong moral principles, employees and would be employees of government in the procurement sector should be obliged to undergo some form of background integrity test before they are engaged. This will assist the procurement system in having professionals with less knack for unethical behaviours and will ultimately bring efficiencies and effectiveness in the procurement sector. 


\section{REFERENCES}

Ayoyi, I. R., \& Mukoswa, R. O., (2015) Ethical issues in public procurement in Kenya", International Journal of scientific and Research publications, Vol. 5, issue 9, ISSN 2250 -3153.

Bessong, P. K., Esikot, dorenyin F., Kankpan, K., \& Esemi, S. (2018). Fiscal Policy Impact on Performance of Electronic Commerce Companies in Nigeria. GNOSI: An Interdisciplinary Journal of Human Theory and Praxis, 1(2), 53-74.

Carter, R. J., \& Kirby, S. K., (2006) Practical Procurement Cambridge: Cambridge University Press.

Chikwe, G. C., \& Obi, E. M. (2016). Rethinking Public Procurement System in Nigeria: The EProcurement Option (A Study of Selected Local Government Areas in Southern Nigeria). International Journal of Business Marketing and Management, 1, 37-48. www.ijbmm.com

Didas, B. (2008), "Recalling where African Procurement reforms began". Procurement News, 2(21), pp.16-17.

Duraku, A. (2018). Public Expenditures Through Public Procurement. European Journal of Engineering and Formal Sciences, 3(1), 40. https://doi.org/10.26417/ejef.v3i 1.p40-49

Erridge, A. (2000). "Public Procurement." Public Policy and Administration 15(4):14-24.

Kidzu, T. O., \& Ncha, G. B. (2018). Cultural Globalization and the place of Africa in Cultural Exchange. Ndunode: Special Edition of Calabar Journal of Humanities, 13(1), 300-310.

Mangla, S. K., \& Luthra, S. (2019). Sustainability, Innovation and Procurement. In Sustainability, Innovation and Procurement. https://doi.org/10.1201/9780429 430695
Muhammad, B. A., Adamu, T., \& Ladi, D. (2015). Appraisal of Construction Project Procurement Policies in Nigeria. American Journal of Engineering Research (AJER), 3, 1924. www.ajer.org

Ncha, G. B. (2018). Existential Justice: The Basis for Quality Leadership in Nigeria. CAJOLIS- Calabar Journal of Liberal Studies, 20(1), 337-343.

Nwogwugwu, N., \& Adebayo, A. 0. (2015). Appraisal of Integrity in Public Procurement Processes in Nigeria. IOSR Journal of Business and ManagementVer. I, 17(7), 2319-7668.

https://doi.org/10.9790/487X1771110115

Odhiambo, W., \& Kaman, P., (2009). Public Procurement: Lessons from Kenya, Tanzania and Uganda, OECD Development Centre, Working paper No. 208.

Okpo, O. (2020). Nigeria's Traditional Virtue Ethics and Business: An Ibibio Virtue Ethics Approach to Business Ethics. GNOSI: An Interdisciplinary Journal of Human Theory and Praxis, 3(1), 16-31.

Snider, K. F., \& Rendon, R. G. (2012). Public Procurement: Public Administration and Public Service Perspectives. Journal of Public Affairs Education, 18(2), 327-348. https://doi.org/10.1080/1523680 3.2012.12001687

Stephens, P. (2013) "Procurement Reform and National Development". Public Procurement Journal, combined $18^{\text {th }}$-19th Edition, ISSN 2276-7649, pp. 1011.

Thai, K. V. (2001). Public procurement re-examined. Journal of Public Procurement, 1(1), 9-50. https://doi.org/10.1108/jopp-0101-2001-b001

UN Procurement Practitioners handbook (November, 2006).

Williams-Elegbe, S. (2018). Systemic corruption and public procurement in developing countries: are there 
any solutions? Journal of Public Procurement, 18(2), 131-147. https://doi.org/10.1108/JOPP-062018-009

Wittig, W. A. (1999) "building value through procurement: a focus on
Africa", A paper presented to the $9^{\text {th }}$ International Anti-corruption Conference, (available online@www.legacy.transparncy.org. 